\title{
ESTIMATION OF THE RUNNING COSTS OF AUTONOMOUS ENERGY SOURCES IN TROLLEYBUSES
}

\author{
Piotr Hołyszko', Piotr Zbigniew Filipek ${ }^{2}$ \\ 1 Municipal Transport Company in Lublin, Trolleybus Department, Lublin, Poland, e-mail: pholyszko@mpk.lublin.pl \\ 2 Lublin University of Technology, Faculty of Electrical Engineering and Computer Science, Lublin, Poland, \\ e-mail: piotr.filipek@pollub.pl
}

Received: 2016.08 .16

Accepted: 2016.09.26

Published: 2016.11.01

\begin{abstract}
The article analyses the performance characteristics and operating costs of the three types of trolleybuses equipped with alternative energy sources, which are used by the MPK (Municipal Transport Company) in Lublin. The selected applications are adapted for driving off traction in emergency mode as well as servicing the regular route. Two of them are based on electrochemical batteries and one uses a system with an electric generator driven by an internal combustion engine.
\end{abstract}

Keywords: trolleybus, additional source of energy, electrochemical battery, hybrid system

\section{INTRODUCTION}

Reduction of pollution emitted by combustion engines by introducing electric vehicles becomes a key goal for public transport today, an idea also promoted by the European Union. (Połom et al. 2015). According to these trends, the Municipal Transport Company (MPK) in Lublin updates their vehicles to meet such growing demands and currently, there are 110 trolleybuses in usage for passenger transportation. To increase the reliability and functionality of the public transport in Lublin, MPK is conducting research on the application of autonomic energy sources installed in trolleybuses. (Holyszko 2006), (Siemionek 2013), (Siemionek \& Dziubiński 2015). This coincides in time with a rapid development of traction batteries, supercapacitors, diesel generators and other sources of energy that can be used as an alternative to the catenary power in supplying the trolleybus and its components. Thanks to these developments in this technology, there are more than 70 the trolleybuses, which are equipped with traction batteries and supercapacitors, but there are also hybrids with generators driven by diesel engines.
Such sources of electrical energy allow to use trolleybuses independently of the traction grid, making them competitive when compared to public transport buses driven by internal combustion. After 10 years of experience in this area it is time for an evaluation and comparison of different types of trolleybus applications.

\section{ALTERNATIVE DRIVES IN TROLLEYBUSES}

The main distinguishing feature of trolleybuses with an additional, autonomous source of energy is the ability to use them to perform transport tasks during brief power outages and on routes, in the course of which there are sections where there is no catenary or it is temporarily disabled. In view of the way the auxiliary power supply is used we can distinguish two types of solutions: a source of emergency power and a source of extended operation.

An autonomous source of energy with the features of an emergency power supply allows only to maneuver and cover very short sections of the route. In selecting the parameters of such a source the traction parameters of the dynamic drivetrain 
and the work of auxiliary systems are not a priority. Due to the fact that such tasks usually require low-capacity batteries or supercapacitors, the driving range of the trolleybus when powered by an autonomous power source is less than $1 \mathrm{~km}$, and additional functions such as air conditioning are not active. The main advantages and benefits of the use of emergency power sources are:

- leaving the intersection or getting to the nearest bus stop in case of power failure in the electric traction;

- avoiding obstacles turning up in the streets e.g. as a result of accidents;

- ability to use the traction through junctions with a limited number of the catenary's torsional relations;

- eliminating the need to use towing services during maneuvering round the depot area in order to use the infrastructure and service and repair equipment;

- access to the end loops and exit to the depot by a shorter route;

- ability to introduce detours or short route journeys without the catenary and the resulting freedom from having to replace trolleybuses with buses during street repairs.

An autonomous source of energy suitable for traction driving allows covering long stretches without drawing power from the catenary. Due to the need to implement the timetables, the dynamic parameters of the drive system and the provision of the work of auxiliary units is in this case of great importance. In order to ensure these parameters, the most commonly used energy sources are in a form of batteries with substantial capacity, sometimes with buffering supercapacitors and generators powered by internal combustion (IC) engines. They provide benefits similar to those previously mentioned, while also offering the possibilities of:

- extending route detours without replacing trolleybuses with buses;

- creating routes and schedules assuming covering great distances when powered by an autonomous source of energy;

- reducing the cost of commuting between the depot and the final loop by selecting the most optimal route;

- replacing buses with trolleybuses.

\section{CURRENT STATUS}

The history of using alternative energy sources for trolleybuses in Lublin began in 2005, when the MPK Lublin commissioned a technical and economic analysis of the trolleybus hybrid drive. Two solutions were analysed then: using a NiMH battery on its own and a NiMH battery connected with a buffering supercapacitor. The latter turned out to be favorable. In MPK Lublin's workshop a trolleybus was constructed with the body of a JELCZ PR110 and an asynchronous drive system, on the roof of which a supercapacitor was built with the capacity of $8.2 \mathrm{~F}$ and the rated voltage of $788 \mathrm{~V}$. In the space under the floor NiMH batteries were mounted with the capacity of $48 \mathrm{Ah}$ and the nominal voltage of $150 \mathrm{~V}$. The supercapacitor was recharged with the battery by the inverter, and then powered the entire drive system together with the auxiliary devices. It also served as a buffer accumulating the regenerative braking energy of the trolleybus. A disadvantage of this solution was losing the braking energy to the braking resistor in the situation when the supercapacitor was fully charged. (Gizinski \& Zulawnik 2009). Also during long climbs uphill the system revealed its imperfections, namely the parameters of the battery did not allow a sufficiently rapid transfer of the energy needed for the supercapacitor. These tests were purely experimental and for formal reasons the reservoirs were removed from the trolleybus and until 2014 it rode as a trolleybus without energy storage.

From 2013 until the end of 2015 the trolleybus fleet operated by MPK Lublin was successively equipped in trolleybuses with autonomous energy sources that could act both in an emergency and offer the use of their energy storage devices for use in traction motion. Figure 1 shows the distribution of the rolling trolleybus stock in Lublin with regard to the alternative power source applied. Currently, the trolleybus rolling stock in Lublin has 110 vehicles, of which 70 are equipped with autonomous energy sources with different properties and parameters, which allows to meet all the needs and tasks put before the most modern trolleybus stock in Poland. 


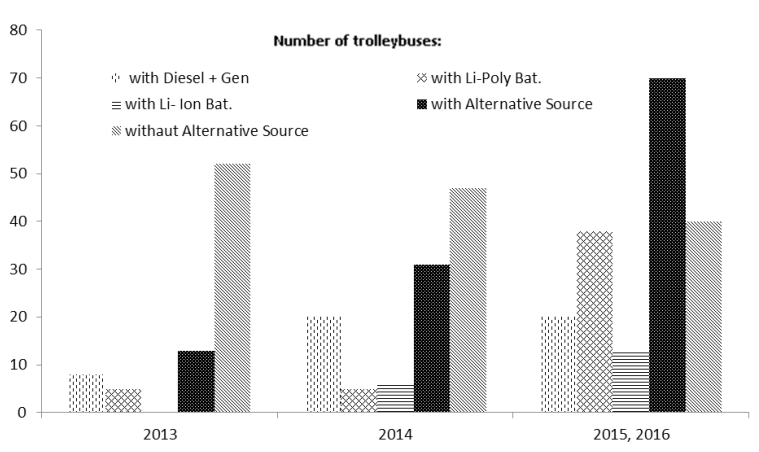

Fig. 1. The state of MPK Lublin's trolleybus fleet in 2013-2016, divided according to the use of an alternative power source.

\section{TROLLEYBUSES WITH AUTONOMOUS SOURCE OF ENERGY}

There are three trolleybus types with additional source energy which are capable for covering long distances without connection to catenary, which are used for public transport in Lublin.

One of the more commonly used alternatively powered trolleybus models in Lublin is URSUS T70116, equipped with a Lithium-Polymer NMC battery. The total capacity of the battery is $34 \mathrm{kWh}$; however, the assumed operation of the battery in the range of $20 \%$ to $60 \%$ DOD (Depth of Discharge) provides a useful capacity only at the level of $13.4 \mathrm{kWh}$, which allows a batterypowered vehicle to cover the distance of up to $10 \mathrm{~km}$. In this solution the autonomous drive system (battery and charger) are mounted on the roof at the rear of the trolleybus (Fig. 2).

The battery has a built-in air conditioning and heating system which allows it to operate them in the Polish climate zone throughout the year,

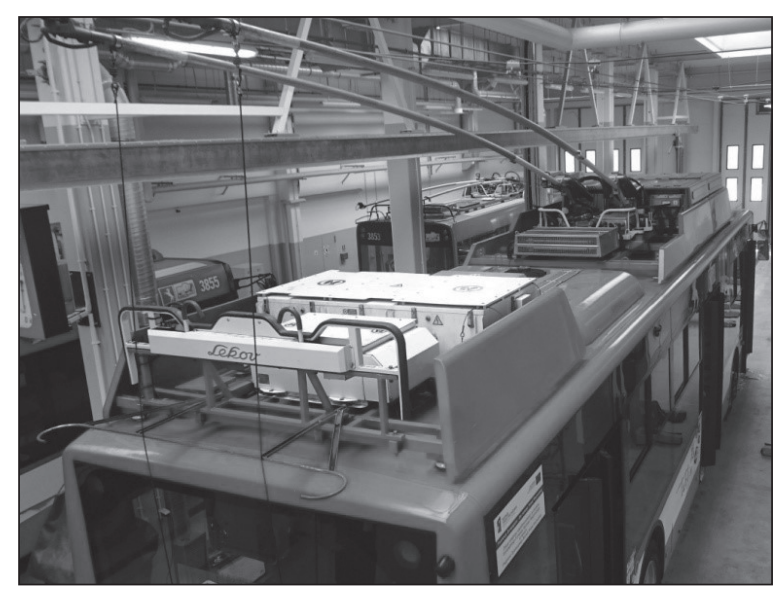

Fig. 2. The of autonomous drive system mounted on the roof of the URSUS T70116 trolleybus. despite the fact that the cells used in the batteries can be recharged when the temperature is between $+5^{\circ} \mathrm{C}$ and $55^{\circ} \mathrm{C}$, while discharged between $-20^{\circ} \mathrm{C}$ and $55^{\circ} \mathrm{C}$. Since recharging the batteries takes place from the catenary by the inverters while driving, at low outside temperatures an earlier starting and heating up of the battery is necessary before its operation. Due to the low capacity of the batteries, when the driving is powered with a traction battery the passenger air conditioning system is automatically switched off, and the heating system can work only in the driver cab with the power limited to $4 \mathrm{~kW}$. One defined cycle for the battery corresponds to a discharge by about $20 \%$, and is synonymous with the trolleybus covering the distance of $5 \mathrm{~km}$ with autonomous power supply. Recharging the battery after driving $5 \mathrm{~km}$ takes about $30 \mathrm{~min}$. With such a definition of cycles the battery life is 20,000 cycles or 6 years. The cost of the use of batteries is calculated on the assumption that in 6 years the battery will go through the number of cycles declared by the manufacturer, the charge-discharge cycle efficiency of the battery is $80 \%$ and the operational costs arising from the periodic inspections are negligible (the battery is maintenance-free), whereas the cost of battery replacement after 6 years will be about $\$ 1,000 / 1 \mathrm{kWh}$. The average power consumption of a trolleybus is $1.32 \mathrm{kWh} /$ $\mathrm{km}$. With these assumptions, the calculated cost of $1 \mathrm{~km}$ on the battery is 1.84 PLN.

SOLARIS Trollino18 trolleybuses has a Lithium-Ion (NMC Hard Carbon) with a capacity of $38 \mathrm{kWh}$ and this is also the energy available when the trolleybus is travelling on an autonomous power supply, which allows to cover c.a. $20 \mathrm{~km}$. The battery consists of two battery blocks connected in parallel, each in the $168 \mathrm{~S} 2 \mathrm{P}$ configuration. The autonomous drive system is installed in the tower at the rear of the trolleybus (Fig. 3).

Both the discharging and charging of the battery can be done at temperatures from $-20^{\circ} \mathrm{C}$ to $55^{\circ} \mathrm{C}$, and the battery's position inside the trolleybus frees it from requiring an internal system of heating and air conditioning. The manufacturer provided a battery life of 6 years or 20,000 cycles, a cycle being defined as discharging down to $20 \%$ DOD, which allows a trolleybus to cover the distance of about $5 \mathrm{~km}$. During autonomous driving both the heating system and air conditioning is automatically switched off. The average power consumption by the trolleybus is $1.8 \mathrm{kWh} / \mathrm{km}$. Given the other assumptions as in the URSUS brand, the cost of $1 \mathrm{~km}$ by an 18-meter trolleybus with autonomous power supply amounts to 2.2 PLN. 


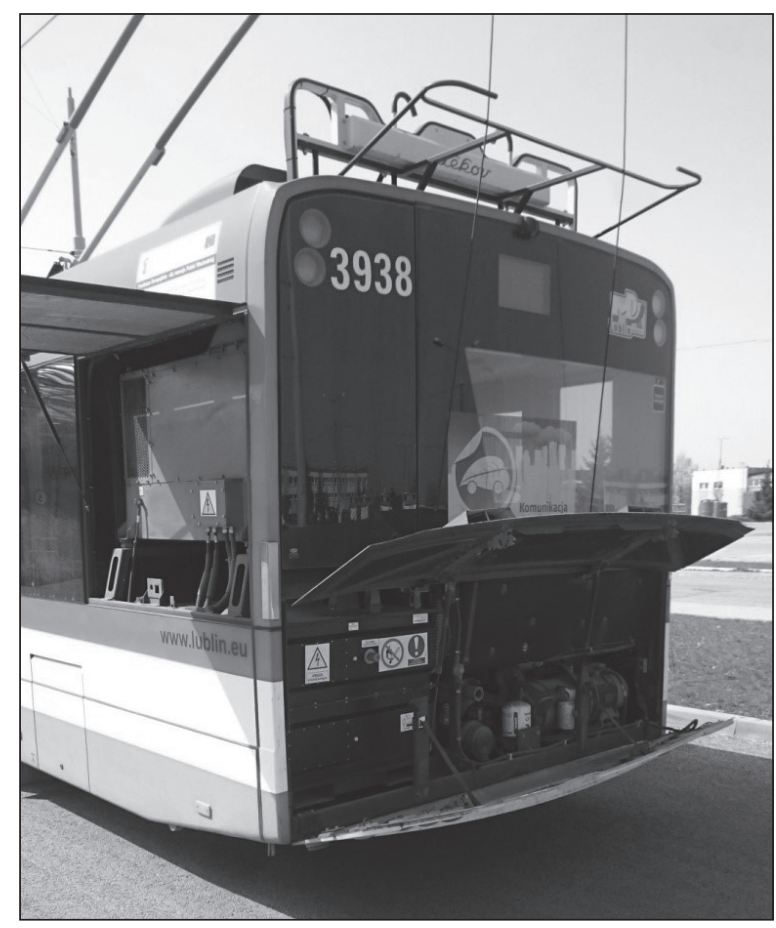

Fig. 3. The tower mounted autonomous drive system in the SOLARIS Trollino18 trolleybus.

A SOLARIS Trollino12 trolleybus is equipped with a generator-combustion autonomous drive system, which without a network connection is working as a serial hybrid system, providing power to all components of the trolleybus. (Holyszko 2016).

In the autonomous drive system an internal combustion engine with a maximum power of $118 \mathrm{~kW}$ drives a synchronous generator with a rated power of $100 \mathrm{~kW}$. The angular speed of the engine are controlled by the trolleybus powertrain ensuring enough power in

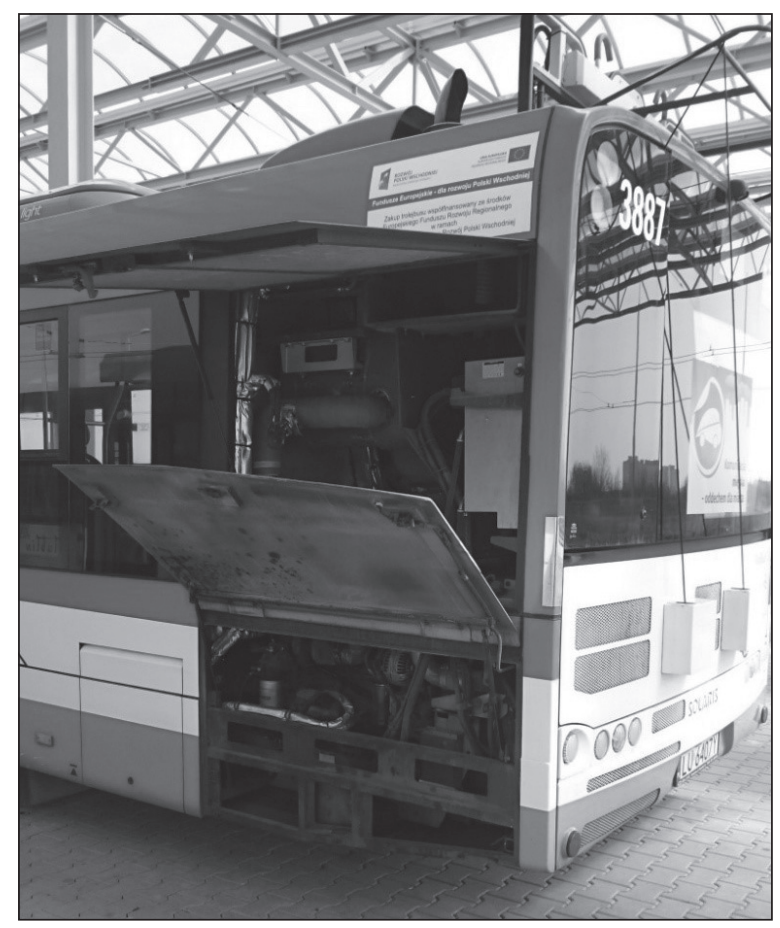

Fig. 4. The tower mounted autonomous drive system in the SOLARIS Trollino12 trolleybus.

particular traction conditions. During electrodynamic braking all of the energy produced is dissipated in the trolleybus brake resistor. The trolleybus range during autonomous operation is limited by the capacity of the diesel tank, which is 125 liters - enough to cover approximately $250 \mathrm{~km}$. At that time, the air conditioning in the trolleybus is automatically disabled while the heating can operate at half power $(20 \mathrm{~kW})$. The average fuel consumption varies in different months (Fig. 5), being on average $55.61 / 100 \mathrm{~km}$.

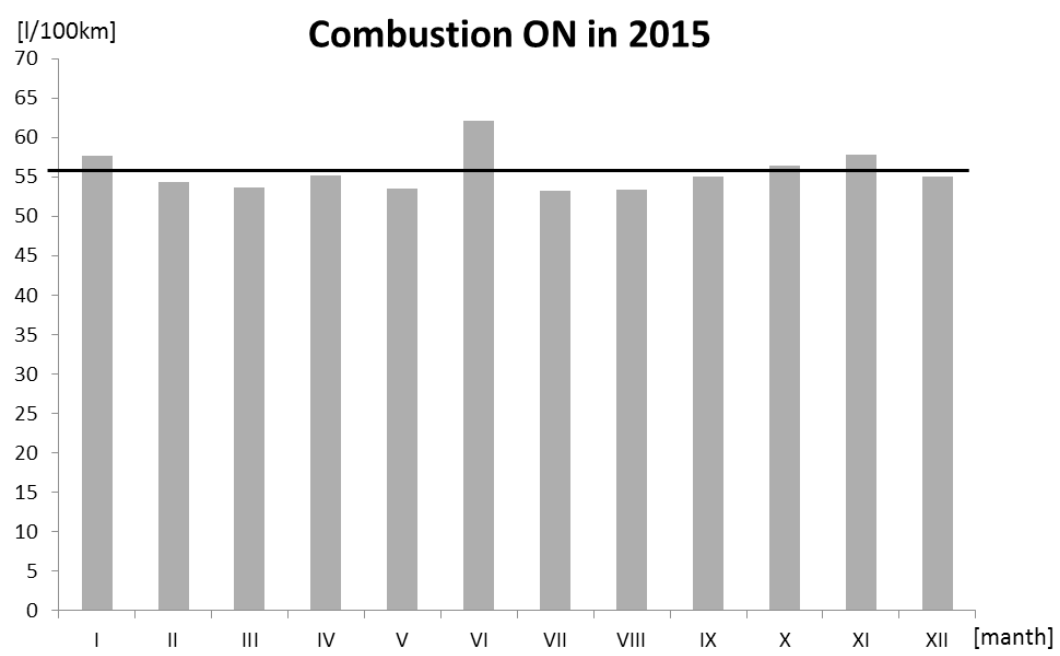

Fig. 5. Average diesel consumption by trolleybuses with a diesel-generator system of autonomous driving by individual months of 2015. 
Diesel consumption is influenced by external temperature; however, the most significant impact is the length of sections which the trolleybus covers after switching to autonomous mode - the shorter the sections, the higher consumption, which can be observed in June 2015.

Assuming that the serial hybrid autonomous drive system will not be replaced throughout the life of the trolleybus, the average cost of diesel is 3.35 PLN per liter, adding the cost of Ad Blue fluid and the annual cost of operating an internal combustion engine in the amount of 66 PLN, $1 \mathrm{~km}$ covered by a trolleybus when powered by a combustion unit is 1.9 PLN.

Comparison of the operating costs of the analysed trolleybuses equipped with alternative energy sources is shown on Figure 6.

This comparison shows that the cheapest trolleybus to operate with an alternative source of energy is an URSUS T70116 equipped with Lithium-Polymer batteries. Slightly more expensive is the vehicle SOLARIS Trollino12 with a hybrid power generation system. The advantage of this solution over the power system of electrochemical batteries is the vehicle's expected lifespan until the end of its roadworthiness, bearing in mind that the lithium batteries must be replaced after approximately 6 years.

The trolleybus equipped with the diesel-hybrid drive system is also seen as the best solution by trolleybus drivers and passengers. They value this vehicle for very good traction features, a long driving range and full functionality of all additional systems (like air-conditioning) during exploitation in the autonomous mode.

It should be noted that the trolleybuses analysed were delivered to MPK between 2013 and 2015. Unfortunately, the solution with the generator driven by a diesel engine is not a zero-emission type, and meets only the EURO-5 emission stan-

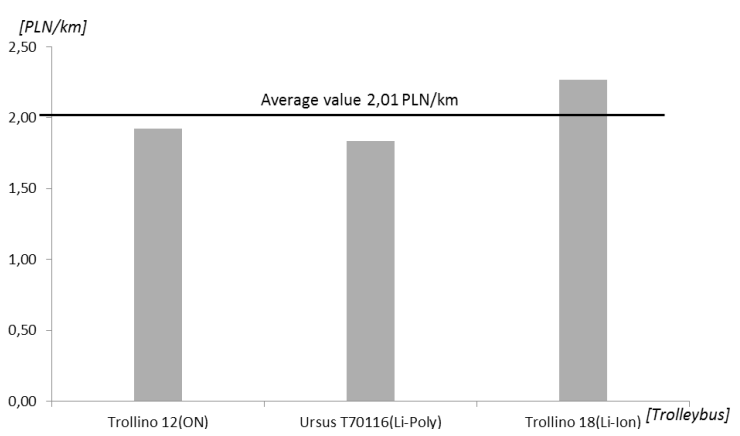

Fig. 6. Average operating costs of trolleybuses with an alternative source of power in the MPK Lublin. dard. In consequence, probably in the near future, it will not meet the new highest environmental standards concerning the means of public transport, which makes this energy source less attractive compared to traction batteries. In the last few years many improvements were introduced in the construction of electrochemical batteries, among them an LTO (Lithium Titanate Oxide) battery technology being the most promising for traction applications. A review of the latest traction batteries and their selection and sizing for trolleybuses and electric buses, as well as the socioeconomic aspects of it, will be the next subject of the authors' research in the future (Jarzyna et al. 2014).

\section{ENERGY COLLECTION SYSTEMS}

An indispensable system of trolleybuses equipped with an autonomous source of energy is automatic current collection. The use of this type of collector provides the following capabilities:

- automatic folding of collectors after the falling away of the collector rod from the catenary when the trolleybus is powered by the catenary an automatic system of current collectors acts as a protection of the traction network from breaking due to falling down collector rods from the catenary. In conventional trolleybuses round drums with an inertia mechanism were used for this purpose. After activation of this mechanism the trolleybus driver had to immediately stop the vehicle, get out of it regardless of where the incident took place, connect the trolleybus to the catenary and drive away trying to catch up with the delay in the timetable. The use of automated systems for current collection in conjunction with autonomous energy sources installed in trolleybuses immediately switches the power source to the autonomous one without the driver having to leave the vehicle in conditions threatening a collision with other traffic and connect the trolleybus again to the catenary.

- intended automatic folding of the current collectors - while following the timetable, which assumes the regular use of the autonomous drive or, in the event of obstacles requiring driving away of the trolleybus from the traction a distance greater than $4.5 \mathrm{~m}$, disconnecting the current collectors and a transition to the alternative power takes place without the driver exiting the trolley. 
- automatic connecting of the collector rods to the catenary can take place only in the appointed place, i.e. under the repositioning roofs installed on the overhead line. The operation of connecting the trolley to the overhead line is shown in Figure 7. After the automatic collector is connected to the catenary, the driver switches the drive system to power supply from the catenary without getting out of the trolleybus.

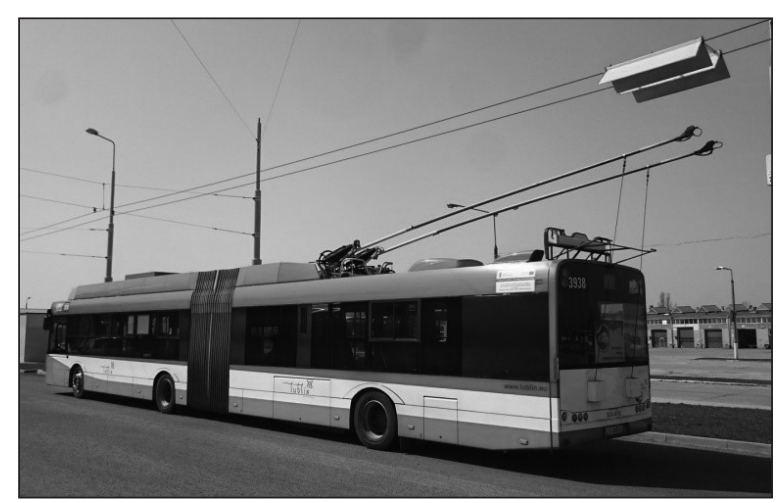

Fig. 7. Automatic connection of a SOLARIS Trollino18 trolleybus to the catenary.

\section{CONCLUSIONS}

The article analyses a few solutions for alternatively-powered trolleybuses operated by the MPK in Lublin. Two of the solutions were based on an electrochemical battery and one on a generator driven by a diesel engine. The calculated operating costs of vehicles are similar, but the leader is the URSUS T70116 trolleybus equipped with Lithium-Polymer batteries, for which the average cost of travel over $1 \mathrm{~km}$ amounts to $1.8 \mathrm{PLN}$. Unfortunately, it is to be expected that the batteries in this vehicle will need to be replaced after approximately 6 years of operation, which is a costly investment. Similar costs at the level of 1.92PLN per kilometer have been found for
SOLARIS Trollino12, which is equipped with a generator driven by an internal combustion engine. This solution is characterised by a significantly higher mileage of up to $250 \mathrm{~km}$ and the lifespan of its alternative power source is estimated at 20 years. Sadly it is not included among zero-emission solutions and in the near future it may be expected not to meet the highest environmental standards for public transport, to be introduced in future legislation. The conclusion is that the investment in trolleybuses with alternative sources of energy in a form of electrochemical batteries may in the long term be advantageous, assuming technological progress of these sources and constantly falling prices for $1 \mathrm{kWh}$ of capacity.

\section{REFERENCES}

1. Gizinski Z. \& Zulawnik M. 2009. Modernizacja i budowa czystego taboru transportu publicznego na terenie miast i w obszarach metropolitalnych - tabor trolejbusowy, Pojazdy Szynowe, No. 3.

2. Hołyszko P. 2006. Właściwości elektrycznych napędów trakcyjnych zasilanych $\mathrm{z}$ autonomicznych źródeł energii. Praca magisterska, Politechnika Lubelska.

3. Jarzyna W., Pawlowski A. \& Viktarovich N. 2014. Technological development of wind energy and compliance with the requirements for sustainable development, Problemy Ekorozwoju, 9(1), 167-177.

4. Połom M., Piasecki A. \& Bartlomiejczyk M. 2015. Charakterystyka autonomiczności trolejbusów - nowe doświadczenia w elektromobilności miejskiej, Logistyka, No. 4.

5. Siemionek E. 2013. Analysis of trolleybus energy consumption. Advances in Science and Technology Research Journal, 7(18), 81-84.

6. Siemionek E. \& Dziubiński M. 2015. Testing energy consumption in the trolleybus and the bus on a chosen public transport line in Lublin. Advances in Science and Technology Research Journal, 9(26), 152-153. 